\title{
Hummocky terrain of the Kalibabak debris avalanche deposit, Lombok Island, Indonesia
}

\author{
Mukhamad N Malawani1 ${ }^{1,2^{*}}$, Franck Lavigne ${ }^{1}$, Danang S Hadmoko ${ }^{2}$, Muh Aris Marfai ${ }^{2}$, and Bachtiar W Mutaqin ${ }^{2}$ \\ ${ }^{1}$ Université Paris 1 Panthéon-Sorbonne, Laboratoire de Géographie Physique, UMR 8591, CNRS, 1 Place Aristide Briand, 92195 \\ Meudon, France \\ ${ }^{2}$ Disaster and Risk Management Research Group, Faculty of Geography, Universitas Gadjah Mada, Jl. Kaliurang, 55281, Indonesia
}

\begin{abstract}
The debris avalanche deposit (DAD) coverage can drastically modify the surrounding landscape of volcanoes. DAD can be distinguished by hummocky irregular surface, jigsaw fissure, and mixing horseshoe shape. Due to its particular shape of a hummock, the topography can be easily identified using DEM (Digital Elevation Model) and satellite imagery. The aim of this study is to characterize hummocky terrain in Lombok Island, which is located in the Kalibabak formation on the Geological map through the geomorphic approach. Hummocky terrain in this study are analyzed using DEM data from DEMNAS (DEM Nasional: 0.27 -arcsecond resolution). Our study of this DAD encompasses seven variables, namely H/L ratio, numbers hummocks, distance to source, slope, area (size), relative height, topographic section, and hummock-spreading shape. A minimum of 756 hills derived from this DEM are considered as hummocks from this DAD, which extends $\sim 18 \mathrm{~km}$ (NS) and $\sim 25 \mathrm{~km}$ (WE) in the central part of Lombok Island. With an area of $\sim 200 \mathrm{~km}^{2}$ and a volume estimated around $8.8 \mathrm{~km}^{3}$, the Kalibabak DAD is more than three times larger than the one of the Mount St-Helens in 1980. The morphology of hummocky terrain is bounded by a sudden change of slope, which is indicated by a river confluence. Average hummock size is 2.7 ha and average distance between each hummock is $150 \mathrm{~m}$ to $300 \mathrm{~m}$. The hummocks are characterized by steep slopes ( $25 \%$ to $45 \%$ ) at the boundary to colluvium plain (debris deposit), which makes them easy to identify using DEM. Hummocks spreading distribution forms a conical-like shape with a $\mathrm{H} / \mathrm{L}$ ratio of 0.13 . The spreading distribution shape, the $\mathrm{H} / \mathrm{L}$ and $\mathrm{V} / \mathrm{L}$ ratios are useful as an input for reconstructing the mechanism of debris avalanche emplacement.
\end{abstract}

\section{Introduction}

A debris avalanche is the product of a large-scale sectorcollapse of a volcanic edifice, often triggered by intrusion, hydrothermal variation, earthquake, intense rainfall, or ice melt $[1,2]$. This mass of rock fragments and soil moves rapidly down a steep mountain slope or hillside, and produces a debris avalanche deposit (DAD). The surrounding landscape of a volcano can be drastically modified due to the coverage of DAD [3]. $\mathrm{DAD}$ can be distinguished by hummocky irregular surface, jigsaw fissure, and mixing horse-shoe shape, which is made up of blocks, sand, and silt under the influence of gravity $[4,5]$. The classical parameter for describing the mechanism of debris avalanche emplacement is the ratio $\mathrm{H} / \mathrm{L}$ between fall height $(\mathrm{H})$, i.e. the maximum elevation of the moved mass, and runout distance (L). Several studies also suggest to take into account the ratio $\mathrm{V} / \mathrm{L}$ between collapse volume $(\mathrm{V})$ and run-out distance (L) [2]. DAD can be classified into three different categories due to its lithofacies: syneruptive DAD (bezymianny and Bandai-type with polymodal grain-size); hybrid DAD (gravitational flows, collisional texture, coarsely stratified, poorly sorted breccias); and lahar-transform DAD (rapid flow dynamics, sand fraction of hyperconcentrated flow deposits) [6].

The geomorphometric approach is powerful to characterize the DAD's topography [4]. The hummocks morphology can be analyzed using a qualitative and quantitative approach in order to: (i) interpret the mechanism of its formation, (ii) calculate the avalanche flow direction, and (iii) trace the magnitude of the sector collapse [7]. For analyzing the origin of the sector collapse and its mode of emplacement, ten variables have been identified, i.e. centroid, distance to crater, relative height, area (perimeter, major and minor axis), sinuosity, axis ratio, circularity index, volume, slope, and aspect (as well as its piedmont) [4]. For reconstructing the estimated volume and the volcano edifice prior to emplacement, the variables are reduced only seven parameters, namely distance to the source, area, top height, volume, major and minor axis, elongated ratio, and displacement angle [8].

Since the review paper on the morphological characteristics of DAD in Indonesia made by Ref. [9] thirty years ago, only a few studies have focused on this particular type of landforms in Indonesia. Besides, these papers only provide brief description regarding the geomorphic characteristics of the hummocky terrain at

\footnotetext{
* Corresponding author: malawani@ugm.ac.id
} 
the feet of individual volcanoes: Krakatoa (1883 eruption) [10]; Papandayan (1772 and 2002 eruption) [11]; and Galunggung (Ten Thousand Hills formation, dated $4200 \pm 150$ BP [12], [13]. In Lombok, a significant hummocky terrain easy to identify using DEM (digital elevation model) and satellite imagery covers a wide area in the central part of this island (Figure 1). This hummocky terrain, which is located at the southern footslope of Mount Rinjani is called Kalibabak formation $(\mathrm{TQb})$ on the geological map of Lombok [14]. It is clearly identified as a DAD due to its brecciated character, which consists of very large lava blocks, locally called "batu hidup" (living rocks).

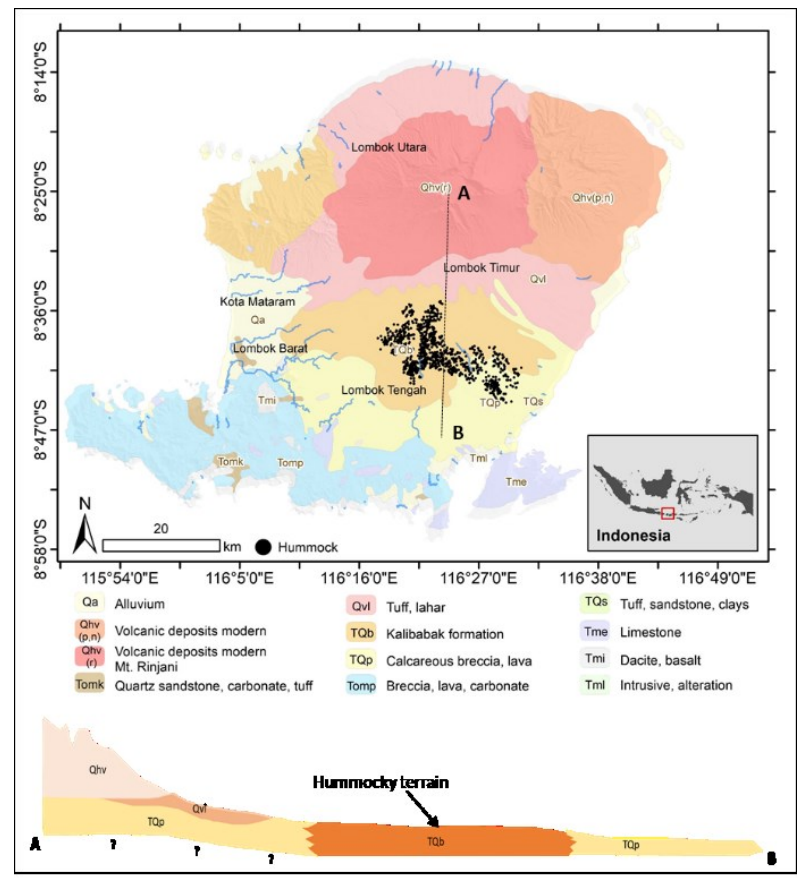

Fig. 1. Hummocky hills in Lombok Island, located in the Kalibabak geological formation (TQb). Based on Geological Map of Indonesia, this formation, composed of breccia and lava, formed during the Upper Pliocene and Lower Pleistocene [14].

The source and mechanism of this debris avalanche remain unknown as well the age of this event. No scarp is visible resulting from a sector-collapse in the morphology of present edifice Rinjani volcano. Therefore, the formation of this DAD almost certainly resulted to a sector-collapse of the Samalas volcano before the total collapse of this edifice during its 1257 CE caldera-forming eruption [16]. The presence of this DAD thus explains why the $13^{\text {th }}$ century PDCs were oriented towards the SE and SW of the island (Figure 2). This study aims to describe for the first time, the widespread hummocky terrain in Lombok Island. This first attempt is only limited to the description and calculation of the geomorphic characteristics of the hummocks, as a basic information for future exploration of the origin and emplacement mechanism of this DAD.

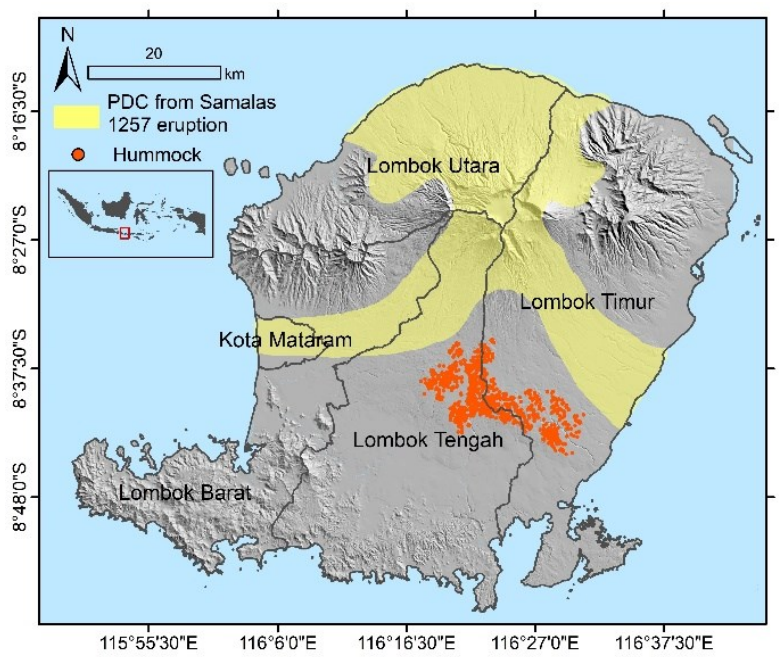

Fig. 2. Location of the DAD in the south foot of Rinjani volcano. The distribution of PDC material from Samalas 1257 CE eruption is curved, avoiding the DAD deposit, which is like an obstacle for PDC distribution.

\section{Methods}

Geomorphic characteristics of hummocky terrain in this study are analyzed using DEM data from DEMNAS (DEM Nasional). DEMNAS (available at http://tide.big.go.id) is appropriate for morphological identification of volcanic landform [15], especially for hummock identification. DENMAS is produced by combining IFSAR ( $5 \mathrm{~m})$, TERRASAR-X $(5 \mathrm{~m})$, ALOS PALSAR $(11.25 \mathrm{~m})$, and adding some stereo-plotting mass point. The resulting product is the national board DEM at 0.27-arcsecond resolution. Additional data were also used, i.e. the Topographical map of Indonesia (known as RBI map) (1:25 000) and the Geological Map sheet of Lombok (1:250 000) which is useful for lithological identification at a regional scale. Due to the common small dimension of hummocks $\left(10 \mathrm{~m}^{2}\right.$ to $100 \mathrm{~m}^{2}$ in area), an elevation model derived from a paired aerial photograph and airborne laser scanner would have provide more accurate data [8], but the acquisition process would have been too costly at the scale of this study.

The methodology to identify and characterize the hummocks in this research follows the previous studies $[4,8]$, with some adjustment. The variables which are usually calculated are the friction coefficient (ratio H/L), numbers of hummocks, distance to source, slope, area (size), relative height, and topographic section. In this study, we also added a variable of hummock-spreading shape. The variables of maximum elevation of the moved mass $(\mathrm{H})$ and the distance to source $(\mathrm{L})$ are both derived from the modelled altitude of Mount Samalas summit before its collapse in $1257 \mathrm{CE}$ [16]. This location roughly corresponds to the one of the present Barujari volcano. Therefore, the distance to source (L) has been calculated by measuring the distance between the Barujari crater to the centroid of DAD.

Number and area of hummocks are identified by digitizing the DEMNAS data (Figure 3). Area of each hummock is calculated from the polygon delineation results. Polygon vector are then converted to a point 
using "feature to point" in ArcGIS to find the centroid of each hummock. Slope in the hummocky terrain is modeled from DEMNAS and classified into five classes using GIS software (Global mapper and ArcGIS). Parallel and perpendicular topographic section are applied in order to observe the morphological expression of hummocks and measure the difference of relative height.
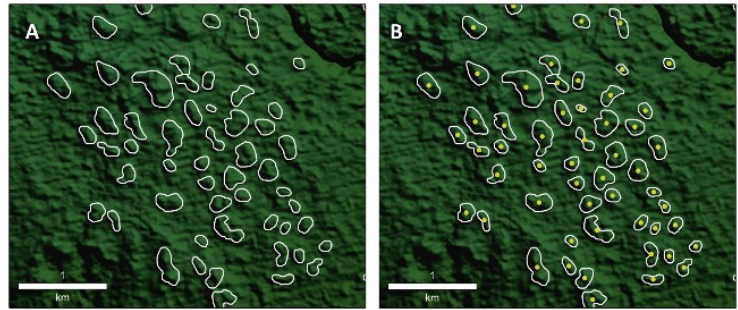

Fig. 3. Topographic expression of hummocky terrain in the study area inferred from DEMNAS. Hummock hills are delineated in white polygon (A), and the centroid of each hummock show in yellow dot (B).

\section{Result and discussion}

\subsection{The Kalibabak debris avalanche deposit}

The spatial distribution of hummocky hills that formed by DAD in Lombok Island is extended in the southern part direction. The direction is also linear to the present river flow direction. Hummocky terrain on the DAD are located in ranges between $18 \mathrm{~km}$ to $36 \mathrm{~km}$ from Samalas former summit. Therefore, the computed maximum runout distance is $\sim 36 \mathrm{~km}$ (in the SE part of Lombok), considering that no distal hummocks have been entirely buried by more recent deposits. This travel distance of debris avalanche in Lombok is in the range of the DAD in Whangaehu, Ruapehu volcano [17], but farther than the one of Mont-St Helens (USA), Bezymianny (Russia), or any debris avalanche in Japan, where the DAD's distance is below $25 \mathrm{~km}$ [18].

The DAD covers $\sim 18 \mathrm{~km}$ NS and $\sim 25 \mathrm{~km}$ WE. The morphology of hummocky terrain is remarkable compared to the surrounding. In the northern part of the hummock field, the morphology changes gradually from smooth rolling plain into rough undulating plain. In the southern part of hummocky terrain, there are suddenbreak of slope to flat morphology (Fig. 4). The different elevation between DAD and alluvial plain is ranging from $\sim 30 \mathrm{~m}$ to 60 meters, or 45 meters on average. This break of slope is assumed to be the DAD boundary. This boundary does not always coincide with the hummock, but there is an area filled by sediments, which probably forms a piedmont in the tail of the DAD [4].

The drainage density in non-DAD topography is relatively denser than in DAD. The sudden-break of slope is also indicated by the increasing of stream order due to many of river confluence (Figure 4). The border made from sudden-break of slope is considered as DAD boundary, which also coincides with a present river channel. This river is extended from NW direction into SE. RBI data shows that this river channel was unique because perpendicular to other river channels (Fig. 5). Generally, the boundary of the Kalibabak Formation (TQp) indicates the one of the DAD. However, due to the small scale of the geological map ( $1: 250000)$, the DAD boundary is needed to be detailed for debris avalanche characterization.

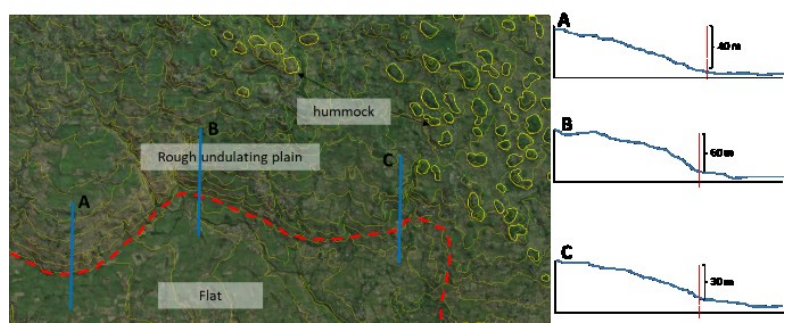

Fig. 4. The sudden-break of slope identified as an estimated boundary of DAD. Profile Graph A, B, and C shows that the slope in DAD is distinct from non-DAD topography.

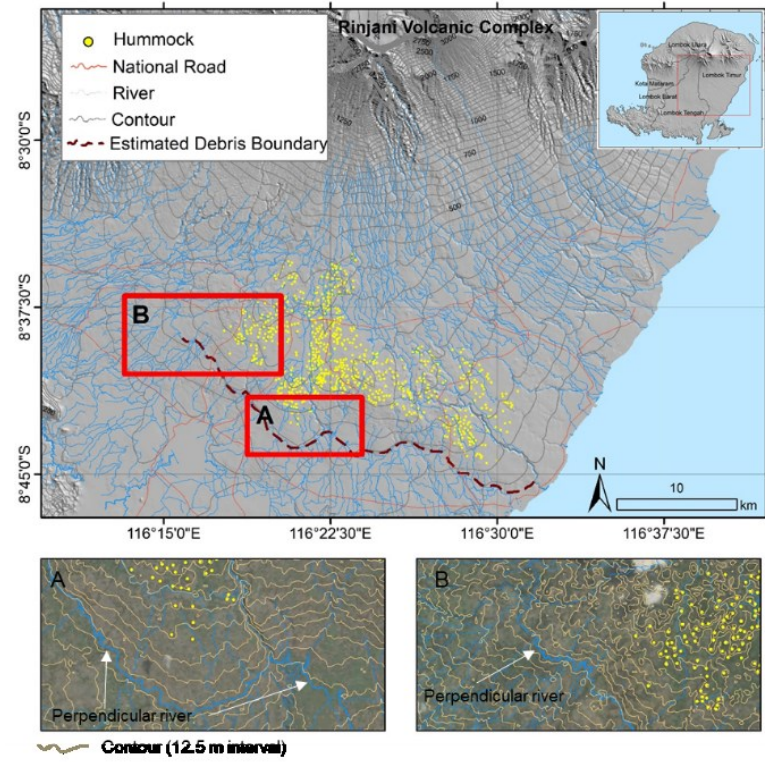

Fig. 5. Estimated boundary of the Kalibabak DAD in Lombok is indicated by present river channel, which is perpendicular to the majority of river flow direction. This river also become a border between steep and flat morphology.

The friction coefficient $\mathrm{H} / \mathrm{L}$ of the avalanche deposit in Lombok is 0.13 , i.e., nearly similar to those studied at El Misti, and St. Helens [6, 19]. The mechanism of emplacement can be assessed by the value of $\mathrm{H} / \mathrm{L}$ ratio. Lower $\mathrm{H} / \mathrm{L}$ ratio indicates a greater mobility of debris avalanche. DAD which have low $\mathrm{H} / \mathrm{L}$ ratio are often associated witha blast, e.g. Bezimiany and St. Helens [19]. Slide and lateral spreading are also influenced the debris avalanche to have greater mobility with lower $\mathrm{H} / \mathrm{L}$ ratio [20]. The mechanism of avalanche in Lombok Island remains unknown. However, based on the value of $\mathrm{H} / \mathrm{L}$ ratio, the mechanism of emplacement in Samalas is supposedly similar with St. Helens and Bezimiany or might be influenced also by slide and lateral spreading.

Based on the Kalibabak formation (TQb) in the geological map and the reconstructed limits of the hummocks field derived from the DEM, the DAD area is $195 \mathrm{~km}^{2}$. Our rough estimation of the DAD thickness at different elevation gives an average thickness is $45 \mathrm{~m}$ (Figure 4). Therefore, the total volume of the DAD is $\sim 8.8 \mathrm{~km}^{3}$. Geo-electrical sounding will improve the accuracy of thickness data in the near future, with a method similar to that applied by Ref. [21] to estimate the $1257 \mathrm{CE}$ PDC thickness in eastern part of Lombok 
Island. The area and volume of Kalibabak DAD is higher than three other, i.e. Bezimiany, St. Helens, and $\mathrm{SHV}$, as well as the V/L ratio. Sliding and spreading of the debris avalanche can be assessed from $\mathrm{V} / \mathrm{L}$ ratio. Higher value of $\mathrm{V} / \mathrm{L}$ indicates that spreading is dominant. In contrast, if $\mathrm{V} / \mathrm{L}$ ratio is lower, the sliding process is dominant [22]. Thereforehe value of extended area and $\mathrm{V} / \mathrm{L}$ in Kalibabak DAD allow us to conclude that spreading process is dominant compared to the sliding process.

Table 1. Comparison of the $\mathrm{H} / \mathrm{L}$ and $\mathrm{V} / \mathrm{L}$ ratio between debris avalanche in this study and other [19].

\begin{tabular}{|c|c|c|c|c|c|}
\hline Volcano & $\mathbf{L}$ & $\begin{array}{c}\text { Area } \\
\left(\mathbf{k m}^{\mathbf{2}}\right)\end{array}$ & $\begin{array}{c}\text { Volume } \\
\left(\mathbf{( k m}^{\mathbf{3}}\right)\end{array}$ & $\mathbf{H} / \mathbf{L}$ & $\mathbf{V / L}$ \\
\hline Bezymianny & 22 & 36 & 0.5 & 0.09 & 0.02 \\
\hline St. Helens & 25 & 64 & 2.5 & 0.12 & 0.1 \\
\hline $\begin{array}{c}\text { Soufrière } \\
\text { Hills Volcano } \\
\text { (SHV) }\end{array}$ & 4.5 & 1.7 & 0.05 & 0.22 & 0.01 \\
\hline $\begin{array}{c}\text { Samalas (this } \\
\text { reserach) }\end{array}$ & 28 & 195 & 8.8 & 0.13 & 0.31 \\
\hline
\end{tabular}

The DAD of Lombok forms a digital-shaped DAD (Figure 6). This distribution shape is delineated by connecting the outermost spreading hummocks. Compared to four other hummock-spreading shape $[4,7,8]$, Lombok DAD has the farthest reach. Hummock spreading in Erciyes volcano has similar shape with Lombok, but thinner and shorter. Other three hummock spreading such as in Jocotitlan, Usu, and Shiribetsu volcano formed hexagonal shape with almost similar wide range. The differences of DAD and hummock spreading is influenced by initial topography of buried landscape, indeed the volume, material, and triggering factor of sector collapse play a role. Therefore, the identification of hummock-spreading shape is also useful for reconstructing mechanism of debris avalanche emplacement. This approach also useful for supporting the mechanism indication from $\mathrm{H} / \mathrm{L}$ and $\mathrm{V} / \mathrm{L}$ ratio.

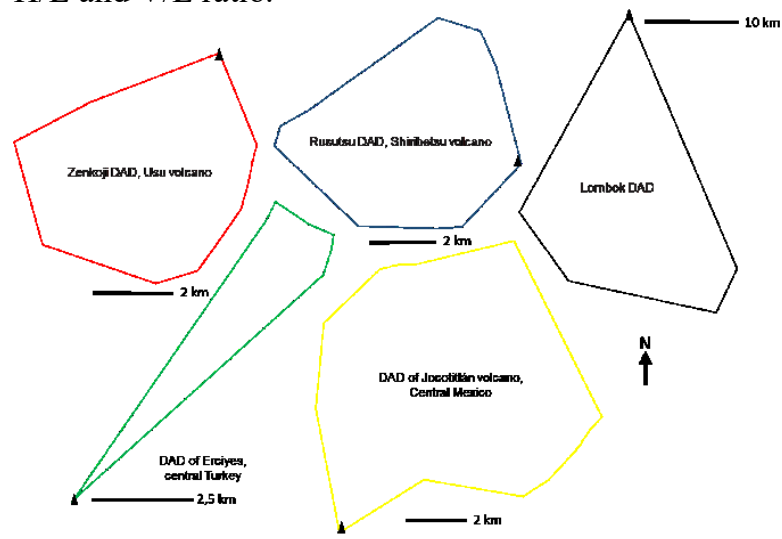

Fig. 6. Comparison of hummock-spreading shape in various $\mathrm{DAD}[4,7,8]$. This delineation is useful for understanding the emplacement mechanism of debris avalanche.

\subsection{Morphometry of Hummocks}

The number of hummocks calculated using DEMNAS is 756 hills. This number is underestimated due to the delineation scale and minimum mapable area due to
DEMNAS resolution. Hummocks in this area are supposed $>1,000$ if identified using a detailed elevation model or field census. However, Although underestimated, this number is still higher than 13 other DAD in Japan, but less than three other massive DAD in this country, e.g. Kisakata (1185 hills), Ura-bandai (1235 hills), Okinajima (900 hills) [23]. The number of hummocks of the Kalibabak DAD is limited in the uppermost and lowermost distance with only 9 and 14 hummocks found. The distribution of hummock number and size based on their distance to estimated source is shows in Fig. 7.
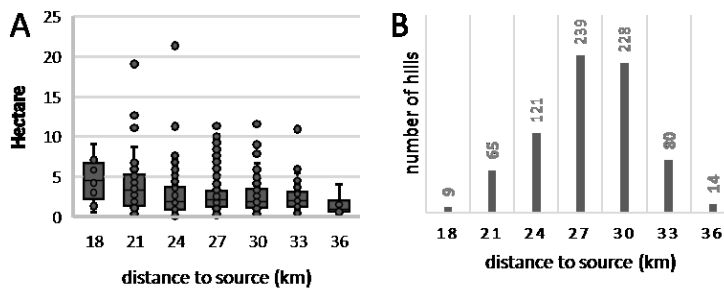

Fig. 7. Comparison between area and distance (A); number and distance $(\mathrm{B})$ of the hummock in Lombok DAD.

Hummocks size of the Lombok DAD varies as identified from DEMNAS. The widest hummock is measured with an area of $21.4 \mathrm{ha}$, while the smallest one is $0.1 \mathrm{Ha}$. Both of the largest and smallest areas of hummock are located within a radius of $24 \mathrm{~km}$ from its estimated source (Figure 8). The average hummocks areas in Lombok DAD is 2.7 ha. Compared to the hummock size of the seven DAD in Japan [18], hummocks in Lombok is relatively similar with predominantly in the size 0.1-10 ha. Only a few hummocks have an area $>10$ ha.

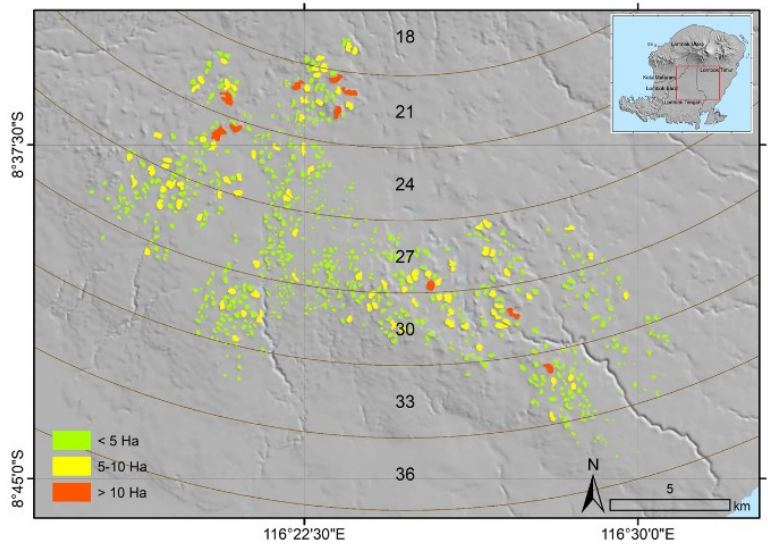

Fig. 8. Distribution of hummocks based on their distance to the source.

The topographic sections parallel and perpendicular to the main direction of debris avalanche display different morphological expressions. Profile from perpendicular direction (1-2) of the volcanic slope shows that the average distance of each hummock is $\sim 300 \mathrm{~m}$, but in the parallel direction (A-B) the distance is about half $(\sim 150 \mathrm{~m})$ (Figure 9$)$. The perpendicular topographic section shows that the DAD's shape is convex. It is different from the parallel section that shows topography gradually sloping. 


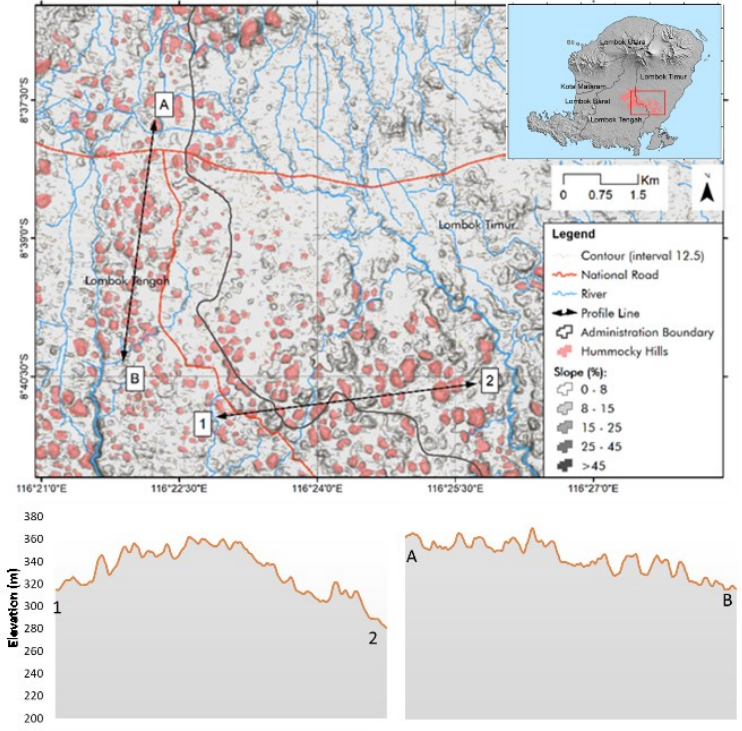

Fig. 9. Topographic sections in the hummock field of the Kalibabak DAD. Topographic sections 1-2 and A-B shows a significant difference between perpendicular and parallel topographic expression in hummocky terrain.

The hummocks height is relatively similar if measured in parallel direction, but in perpendicular section, their height is varying. Hummocks height measured from the topographic section has an average $10 \mathrm{~m}$ to $20 \mathrm{~m}$. Along the topographic section A-B, the smallest hummock is only three meters high, whereas the maximum height is $>25 \mathrm{~m}$ (Figure 10). This maximum height is higher than the one measured at the Erciyes volcano debris avalanche [8].

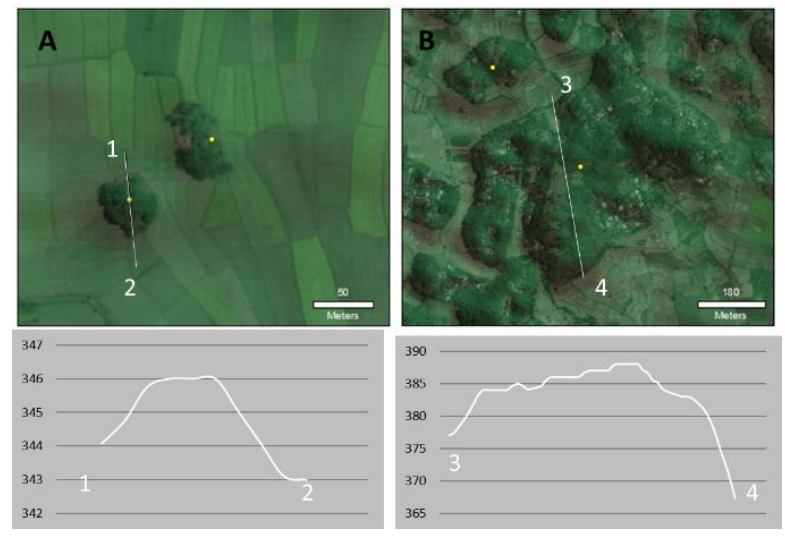

Fig. 10. Profile comparison of the smallest (A) and the biggest (B) hummock in the Kalibabak DAD.

The formation of hummocks in DAD has steep slope ( $25 \%$ to $45 \%$ ), which formed a boundary to colluvium (sediment infill) plain and makes easy to identify using DEM data. It is important to note that hummock-like shape are also found in other landscapes, such as in karst landscape. Hummock hills on DAD have a similar shape to the hilly area on a karst system if identified using DEM data. Their difference is on the distribution characteristic. The hummocky hill formed by debris avalanche are rather distant and sprawl compared to the conical hill on karst system. It is also forms a close system (cockpit morphology) in karst [24].

\section{Conclusion}

The main geomorphometric characteristics of the Kalibabak DAD in Lombok have been calculated for the first time, using DEMNAS data. They were analyzed at two spatial scales: that of the whole DAD deposit (e.g., distance to source, surface, volume, ratio $\mathrm{H} / \mathrm{L}$ and $\mathrm{V} / \mathrm{L}$, spreading shape, etc.), and individual hummocks (e.g., number, height, area, slopeand shape). Our preliminary results underline that the Kalibabak DAD is much larger than many of well-studied similar events, e.g. it is more than three times larger than the 1980 Mount St-Helens DAD. Therefore, it may have drastically changed the pre-event morphology of Lombok island. The value of ratio $\mathrm{H} / \mathrm{L}, \mathrm{V} / \mathrm{L}$, and hummock-spreading shape indicates that the Kalibabak debris avalanche have had a great mobility due to spreading process. Number of hummock in this study is higher than the majority hummocks in Japan, but similar in hummocks size. Most of hummock in Kalibabak DAD have height $10 \mathrm{~m}$ to $20 \mathrm{~m}$. The geomorphometric characteristic of hummocky terrain in this study is useful for a future deeper study of the Kalibabak DAD, in order to: (i) obtain a better estimation of the DAD volume using geophysical tools; (ii) better analyse the lithological characteristics of the lava; (iii) understand the triggering process of the rupture; and (iv) discover the age of this event, which might be much younger than suggested in the geological map.

The first author would like to acknowledge the Ministry of Education and Culture (Kemendikbud) Republic Indonesia for BPPLN scholarship. This paper has been written as part of a collaborative project between Universitas Gadjah Mada and University of Paris 1 Panthéon-Sorbonne, also supported by PDUPT research grant (No. 1675/UN1/DITLIT/DITLIT/PT/2020). Authors thank to Ghalih N. Wicaksono and Riha A. Muhammad for mapping assistance. The authors also thank to anonymous reviewers for his/her constructive comments.

\section{References}

1. L. Siebert, J. Volcanol. Geotherm. Res, 22: 163197, (1984).

2. A. Delcamp, M. Kervyn, M. Benbakkar, S. Kwelwa, D. Peter, Landslides, 833-847, (2017).

3. A. Cortés, J.L. Macías, L. Capra, V.H. Garduñomonroy, J. Volcanol. Geotherm. Res, 197: 52-66, (2010).

4. S. Salinas, J. López-Blanco, Geomorphology, 123,1-2: 142-153 (2010).

5. L. Vezzoli, T. Apuani, C. Corazzato, A. Uttini, J. Volcanol. Geotherm. Res., 332: 51-70 (2017).

6. K. Bernard, B.V.W. De Vries, J. Thouret, J. Volcanol. Geotherm. Res., 371: 116-136 (2019).

7. H. Yoshida, Geomorphology, 223: 67-80 (2014).

8. Y.S. Hayakawa et al., Nat. Hazards Earth Syst. Sci., 18,2: 429-444 (2018).

9. N. MacLeod, Geol Indones., 12: 563-601, 1989.

10. G. Camus, M. Diament, M. Gloaguen, GeoJournal, September (1992).

11. A. Nursalim, N. Sulaksana, E. Sukiyah, Bull. Sci. Contrib., 14: 45-54 (2016). 
12. S. Bronto, Volcanic geology of Galunggung, West Java, Indonesia, p. 511 (1989).

13. H.D. Dono, L.D. Setjadji, Pros. Semin. Nas. Kebumian ke-7, p. 30-31 (2014).

14. S. Mangga, S. Atmawinata, B. Hermanto, B. Setyogroho, T. Amin, Geological Reserach and Development Centre, Bandung (1994).

15. M.N. Malawani, Subandriyo, G.N. Wicaksono, T. Handayani, IOP Conf. Series: Earth and Environmental Science 451, (2020).

16. F. Lavigne et al., Proc. Natl. Acad. Sci. U. S. A., 110, 42:16742-16747 (2013).

17. R. Keigler et al., Geomorphology, 133, 1-2: 57-79 (2011)

18. H. Yoshida, T. Sugai, H. Ohmori, Geomorphology, 136, 1: 76-87 (2012).

19. A. Belousov, B. Voight, and M. Belousova, Bull Volcanol, 69: 701-740 (2007).

20. H. Glicken, Rockslide-debris avalanche of May 18, 1980, Mount St. Helens volcano, Washington, (1996).

21. B.W. Mutaqin et al., Geomorphology, 327, 338350 (2019).

22. L. Staron, E. Lajeunesse, Geophys. Reserach Lett., 36, 12 (2009).

23. H. Yoshida, Geosci., 6, 5 (2016).

24. E. Haryono and M. Day, J. Cave Karst Stud., 66, 2: 62-69 (2004). 